\title{
Delivery Room Management of Very Low Birth Weight Infants in Germany, Austria And Switzerland - A Comparison of Protocols
}

\author{
C. C. Roehr ${ }^{1}$, S. Gröbe ${ }^{1}$, M. Rüdiger ${ }^{2}$, H. Hummler ${ }^{3}$, M. Nelle ${ }^{4}$, H. Proquitté ${ }^{1}$, H. Hammer ${ }^{1}$, \\ G. Schmalisch ${ }^{1}$ \\ ${ }^{1}$ Department of Neonatology, Charité Universitätsmedizin Berlin, Germany \\ ${ }^{2}$ Department of Neonatology, Carl-Gustav-Carus Universität Dresden, Germany; formerly at University of Innsbruck, Austria \\ ${ }^{3}$ Department of Neonatology, Universitätsklinikum Ulm, Ulm, Germany \\ ${ }^{4}$ Department of Neonatology, Universitätsspital Bern, Bern, Switzerland
}

\begin{abstract}
Background: Surveys from the USA, Australia and Spain have shown significant inter-institutional variation in delivery room (DR) management of very low birth weight infants (VLBWI, <1500g) at birth, despite regularly updated international guidelines.

Objective: To investigate protocols for DR management of VLBWI in Germany, Austria and Switzerland and to compare these with the 2005 ILCOR guidelines.

Methods: DR management protocols were surveyed in a prospective, questionnaire-based survey in 2008. Results were compared between countries and between academic and non-academic units. Protocols were compared to the 2005 ILCOR guidelines.

Results: In total, 190/249 units (76\%) replied. Protocols for DR management existed in $94 \%$ of units. Statistically significant differences between countries were found regarding provision of $24 \mathrm{hr}$ in house neonatal service; presence of a designated resuscitation area; devices for respiratory support; use of pressure-controlled manual ventilation devices; volume control by respirator; and dosage of Surfactant. There were no statistically significant differences regarding application and monitoring of supplementary oxygen, or targeted saturation levels, or for the use of sustained inflations. Comparison of academic and non-academic hospitals showed no significant differences, apart from the targeted saturation levels $\left(\mathrm{SpO}_{2}\right)$ at $10 \mathrm{~min}$. of life. Comparison with ILCOR guidelines showed good adherence to the 2005 recommendations.

Summary: Delivery room management in German, Austrian and Swiss neonatal units was commonly based on written protocols. Only minor differences were found regarding the DR setup, devices used and the targeted ranges for $\mathrm{SpO}_{2}$ and $\mathrm{FiO}_{2}$. DR management was in good accordance with 2005 ILCOR guidelines, some units already incorporated evidence beyond the ILCOR statement into their routine practice.
\end{abstract}

Key words: delivery room management, preterm, neonate, VLBWI, guidelines, surfactant, oxygen, saturation, monitoring.
Abbreviations: $\mathrm{AU}=$ Austria; $\mathrm{BW}=$ birth weight $\mathrm{CO}_{2}$ = carbon dioxide; $\mathrm{CPAP}=$ continuous positive airway pressure; $\mathrm{CH}=$ Switzerland; $\mathrm{DE}=$ Germany; $\mathrm{DR}=$ delivery room; ERC = European Resuscitation Council; FI-bag = flow-inflating bag; $\mathrm{FiO}_{2}=$ fraction of inspired oxygen; GA = gestational age; ILCOR = International Liaison Committee on Resuscitation; NICU = neonatal intensive care unit; n.s. = not statistically significant; $\mathrm{O}_{2}=$ oxygen; $\mathrm{RR}=$ respiratory rate; $\mathrm{SI}-\mathrm{bag}=$ self-inflating bag; $\mathrm{SpO}_{2}=$ peripheral oxygen saturation; VLBWI = very low birth weight infant (birth weight less than 1500g)

\section{BACKGROUND}

Survival of very low birth weight infants (VLBWI, birth weight less than $1500 \mathrm{~g}$ ) is dependent on professional perinatal management [4]. For successful delivery room (DR) management various aspects of the postnatal adaption process need to be considered such as the support of the thermal adaptation, airway management, breathing, circulation and metabolism [17]. The consistent provision of high quality care in a field as challenging and stressful as neonatal resuscitation has been shown to be improved by the adherence to standardized protocols [26]. An up to date, evidence based protocol and modern set-up of the DR, recently referred to as ,the delivery room neonatal care unit" (DR NICU, as by Vento et al.), helps ensure a successful and coordinated, patient centred team effort [12, 28]. Thanks to the extensive research interest in neonatal resuscitation, good quality evidence has become available from an increasing number of large randomized controlled trials on almost all fields of DR management over the course of the past decade [9, 29].

Different international organizations have dedicated their work towards the provision of up to date recommendations on the DR management of neonates, namely the European Resuscitation Council [3] and the International Liaison Committee on Resuscitation Council [7]. In seeking to provide up to date recommendations on the management and on the best 
equipment used during resuscitation, ILCOR engages more than 500 physicians, collaborating to evaluate the best available evidence from over 20.000 papers in search of the best evidence. These recommendations are distributed through the scientific literature [1]. Furthermore, the practice of DR management is widely being taught in various internationally recognized training programmes (neonatal advanced life support $=$ NALS, neonatal resuscitation program $=\mathrm{NRP})($ see Leone [10]).

Despite the above efforts to standardize delivery room management of VLBWI neonates, national surveys from Australia, the USA, Italy and Spain have shown wide and significant inter-institutional variations in DR management of VLBWIs. These were found regarding, for instance, the equipment used for resuscitation and for monitoring, or regarding the targeted parameters during resuscitation $[8,10,13$, 27].

The aim of our study was to investigate the current state of DR management of infants with birth weight $<1500 \mathrm{~g}$ at birth in German speaking countries (Germany (DE), Austria (AU) and Switzerland (CH)). We wanted to know to which extent the above named recommendations were incorporated in local treatment protocols and whether there was a differences in the implementation between the countries and between academic and non-academic hospitals.

\section{Methods}

We conducted a questionnaire survey on DR management of German, Austrian and Swiss neonatal units. Between October and December 2008 a total of 249 units were approached (DE: 193, AU: $14 \mathrm{CH}: 42$ ). The questionnaire was developed in our clinic and pretested on our Department (Charité Universitätsmedizin Berlin, Germany). Elements from published questionnaires were incorporated to ensure comparability to published data from other surveys [10].

\section{QUESTIONNAIRE}

The questionnaire contained four sections:

- Characterization of the institution: Information was obtained on the level of care and the teaching status of the institution, number of in house births below $1500 \mathrm{~g} /$ year, presence of $24 \mathrm{hr}$ neonatal in house service and number of admissions to the neonatal intensive care unit (NICU) per year. We distinguished between academic children's hospitals or academic teaching hospitals and non-academic children's hospitals.

- Perinatal management: information on late cord clamping, thermal management in DR, and presence of a designated resuscitation area, protocols or guidelines for DR management.

- DR management equipment: Types of ventilator equipment used, means of non-invasive respiratory support systems (bags, T-piece resuscitators, ventilators), use of $\mathrm{CO}_{2}$-detectors, oxygen blenders, pulse oximetry.

- Targeted values: The use of oxygen $\left(\mathrm{O}_{2}\right)$ during DR management, the expected $\mathrm{SpO}_{2}$ saturations at 10 min of age and the titration strategy for adapting $\mathrm{FiO}_{2}$ treatment.

- Surfactant therapy: Protocols for Surfactant administration and dosage.

\section{PROTOCOL}

The questionnaire was sent by posted mail to all German, Austrian and Swiss children's hospitals with NICU facilities, as identified through the address database of the „Gesellschaft für neonatale und pädiatrische Intensivmedizin" (GNPI = society for neonatal and paediatric intensive care medicine). The questionnaire was sent to the head of the neonatal department of each unit. Four weeks after the initial sending, a reminder questionnaire was sent out to the non-compliant institutions, followed by both Email and telephone contact.

\section{Statistical Methods}

The reported characteristics are described by incidences and the differences between countries and academic and non-academic institutions were compared by chi-square test or the exact Fischer test, as appropriate. Chi-square was not calculated if total frequency numbers were $<5$. For statistical evaluation the software Statgraphics (Vers. 5.0, Manugistics Inc., U.S.A.) was used. A p-level of $<0.05$ was accepted as statistically significant.

\section{RESULTS}

A total of 190 of the 249 approached neonatal units replied, the mean response rate was $76 \%$ (DE: 153/193 (79\%), AU: 11/14 (79\%), CH: 26/42 (62\%). Of the received questionnaires the incidence of missing data due to unanswered items was in the median $3.4 \%$ (range $0 \%$ to $23.7 \%$ ). Therefore, in all tables the total number of answers was given. The highest incidence of missing data was regarding the question about presence of a neonatal resuscitation room, the use of flow-inflating bags (FI-bags) and the surfactant treatment.

The characteristics of the responding units are shown in Table 1 . Forty-eight units $(25 \%)$ were academic children's hospitals or teaching hospitals, and 142 $(75 \%)$ were non-academic units. Almost all units (94\%) had written protocols for DR management. There were no statistically significant differences found between the countries' units regarding most items, except for the provision of a $24 \mathrm{hr}$ neonatal in house service and the presence of designated resuscitation area (a special room or cubicle) $(p=0.016$ and 0.019 , respectively) (Table 1 ).

With regards to the clinical practice of DR management, no statistically significant differences between countries were found regarding the measures for thermal control, circulatory volume and $\mathrm{O}_{2}$-monitoring, as shown in Table 2. However, there were differences between countries with respect to the equipment used for DR management (Table 2). Flow-inflating bags are rarely used in DE $(2 \%)$ but in more than $20 \%$ of $\mathrm{AU}$ and $\mathrm{CH}$ units $(\mathrm{p}<0.001)$. In contrast, the use of self- 
Table 1. Demographics of the participating institutions (absolute numbers and percent (\%) in parenthesis).

\begin{tabular}{|c|c|c|c|c|c|}
\hline & $\begin{array}{l}\text { Germany } \\
N=153\end{array}$ & $\begin{array}{l}\text { Austria } \\
\mathbf{N}=11\end{array}$ & $\begin{array}{l}\text { Switzerland } \\
N=26\end{array}$ & $\begin{array}{l}\text { All countries } \\
\mathrm{N}=190\end{array}$ & $\begin{array}{l}\text { Differences } \\
\text { between countries } \\
\text { p-value }\end{array}$ \\
\hline Academic unit & $35 / 153(23)$ & $4 / 11(36)$ & $9 / 26(35)$ & $48 / 190(25)$ & 0.304 \\
\hline Births per year $>1000$ & $122 / 150(81)$ & $7 / 10(70)$ & $18 / 26(69)$ & $147 / 186(79)$ & 0.290 \\
\hline $\begin{array}{l}>50 \text { VLBWI neonates } \\
\text { per year }\end{array}$ & $64 / 152(42)$ & $5 / 11(45)$ & $12 / 26(46)$ & $81 / 189(43)$ & 0.914 \\
\hline $\begin{array}{l}24 \mathrm{hr} \text { in house neonatal } \\
\text { service }\end{array}$ & $148 / 153(97)$ & $11 / 11(100)$ & $21 / 25(84)$ & $180 / 189(95)$ & 0.016 \\
\hline $\begin{array}{l}\text { Designated neonatal } \\
\text { resuscitation room }\end{array}$ & 95/117 (81) & $6 / 9(67)$ & $10 / 19(53)$ & $111 / 145(77)$ & 0.019 \\
\hline $\begin{array}{l}\text { Neonatal treatment } \\
\text { guidelines }\end{array}$ & $140 / 149(94)$ & $11 / 11(91)$ & $24 / 26(92)$ & $174 / 186(94)$ & 0.889 \\
\hline
\end{tabular}

VLBWI $=$ very low birth weight neonate

Table 2. Clinical practice and equipment used for resuscitation of VLBWI (absolute numbers and percent (\%) in parenthesis).

\begin{tabular}{|c|c|c|c|c|c|}
\hline & $\begin{array}{l}\text { Germany } \\
N=153\end{array}$ & $\begin{array}{l}\text { Austria } \\
\mathrm{N}=11\end{array}$ & $\begin{array}{l}\text { Switzerland } \\
N=26\end{array}$ & $\begin{array}{l}\text { All countries } \\
\mathrm{N}=190\end{array}$ & $\begin{array}{l}\text { Differences } \\
\text { between countries } \\
\text { p-value }\end{array}$ \\
\hline \multicolumn{6}{|l|}{$\begin{array}{l}\text { Circulatory volume- and } \\
\text { temperature control }\end{array}$} \\
\hline Late cord clamping & $62 / 145(43)$ & $5 / 10(50)$ & $11 / 24(46)$ & $78 / 179(44)$ & 0.879 \\
\hline Polyethylen foil & $93 / 151(62)$ & $8 / 10(80)$ & $16 / 26(62)$ & $117 / 187(63)$ & 0.504 \\
\hline Head cover & $126 / 151(83)$ & $7 / 10(70)$ & $19 / 26(73)$ & $152 / 187(81)$ & 0.294 \\
\hline \multicolumn{6}{|l|}{$\begin{array}{l}\text { Devices for pressure or } \\
\text { volume control }\end{array}$} \\
\hline FI-bag & $2 / 119(2)$ & $2 / 9(22)$ & $6 / 26(23)$ & $10 / 154(6)$ & $<0.001$ \\
\hline SI-bag & $113 / 136(83)$ & $8 / 9(89)$ & $25 / 26(96)$ & $146 / 171(85)$ & 0.215 \\
\hline with PEEP valve & $98 / 136(72)$ & 4/9 (44) & $20 / 26(77)$ & $122 / 171(71)$ & 0.164 \\
\hline with manometer & $34 / 136(27)$ & $1 / 8(13)$ & $2 / 25(8)$ & $37 / 169(22)$ & 0.093 \\
\hline Neopuff ${ }^{\circledR}$ & $56 / 136(41)$ & $8 / 10(80)$ & $5 / 25(20)$ & $69 / 171(40)$ & 0.004 \\
\hline Respirator & $66 / 136(49)$ & $2 / 10(20)$ & $4 / 25(16)$ & $72 / 171(42)$ & 0.004 \\
\hline $\begin{array}{l}\text { Other pressure control } \\
\text { devices }\end{array}$ & $5 / 136(4)$ & $0 / 10(0)$ & $2 / 25(8)$ & $7 / 171(4)$ & 0.459 \\
\hline $\begin{array}{l}\text { Devices with volume } \\
\text { control (respirator) }\end{array}$ & $59 / 148(40)$ & $4 / 10(40)$ & $5 / 25(20)$ & 68/183 (37) & 0.161 \\
\hline $\begin{array}{l}\text { Devices without any } \\
\text { pressure / volume control }\end{array}$ & $1 / 147(1)$ & 0/11 (0) & $2 / 26(8)$ & $3 / 183(2)$ & - \\
\hline \multicolumn{6}{|l|}{$\begin{array}{l}\mathrm{O}_{2} \text {-therapy and } \\
\text { monitoring }\end{array}$} \\
\hline Pulse oximetry & $149 / 150(99)$ & $9 / 10(90)$ & $26 / 26(100)$ & 184/186 (99) & - \\
\hline $\mathrm{O}_{2}$-blenders & $148 / 152(97)$ & $11 / 11(100)$ & $24 / 25(96)$ & 183/188 (97) & 0.248 \\
\hline $\mathrm{CO}_{2}$-detectors & $12 / 149(8)$ & 4/11 (36) & $3 / 26(11)$ & 19/186 (10) & 0.011 \\
\hline $\begin{array}{l}\text { Gas heating and } \\
\text { humidification }\end{array}$ & $62 / 150(41)$ & 2/11 (18) & $13 / 24(54)$ & $17 / 185$ (42) & 0.132 \\
\hline
\end{tabular}

FI-bag = flow-inflating bag; SI-bag = self-inflating bag; PEEP $=$ positive end expiratory pressure

inflating bags (SI-bags) was common, with $85 \%$ for all countries, without statistically significant differences. In particular, they were used in $83 \%$ of DE, $89 \%$ of $\mathrm{AU}$ and $96 \% \mathrm{CH}$ units. SI-bags were often used to- gether with PEEP valves (71\% for all countries). Less than a quarter of all units used pressure manometers together with SI-bags. Pressure controlled manual resuscitation devices (T-piece resuscitators) were used in 
Table 3. Primary target values and parameter settings (absolute numbers and percent (\%) in parenthesis).

\begin{tabular}{|c|c|c|c|c|c|}
\hline & $\begin{array}{l}\text { Germany } \\
\mathrm{N}=153\end{array}$ & $\begin{array}{l}\text { Austria } \\
\mathbf{N}=11\end{array}$ & $\begin{array}{l}\text { Switzerland } \\
N=26\end{array}$ & $\begin{array}{l}\text { All countries } \\
\mathrm{N}=190\end{array}$ & $\begin{array}{l}\text { Differences } \\
\text { between countries } \\
\text { p-value }\end{array}$ \\
\hline \multicolumn{6}{|l|}{ Oxygen therapy } \\
\hline \multicolumn{6}{|l|}{$\mathrm{FiO}_{2}$} \\
\hline 0.21 & $47 / 147(32)$ & $1 / 11(9)$ & $8 / 25(32)$ & $56 / 183(31)$ & \\
\hline $0.22-0.5$ & $81 / 147(55)$ & 10/11 (91) & $14 / 25(56)$ & $105 / 183(57)$ & 0.241 \\
\hline $0.51-1.0$ & 19/147 (13) & $0 / 11(0)$ & $3 / 25(12)$ & $3 / 183(12)$ & \\
\hline \multicolumn{6}{|l|}{ Target $\mathrm{SpO}_{2}$} \\
\hline$<85 \%$ & $21 / 145$ (14) & $1 / 7(14)$ & $8 / 24(33)$ & $30 / 176(17)$ & \\
\hline $85-90 \%$ & $108 / 145(74)$ & $5 / 7(71)$ & $13 / 24(54)$ & $126 / 176(72)$ & 0.231 \\
\hline$>90 \%$ & $16 / 145(11)$ & $1 / 7(14)$ & $3 / 24(13)$ & 20/176 (11) & \\
\hline High $\mathrm{FiO}_{2}$, taper down & $31 / 152(20)$ & 2/11 (18) & $2 / 25(20)$ & $38 / 188(20)$ & \\
\hline Low $\mathrm{FiO}_{2}$, taper up & $12 / 152(80)$ & $9 / 11(82)$ & $20 / 25(80)$ & $150 / 188(80)$ & 0.984 \\
\hline \multicolumn{6}{|l|}{$\begin{array}{l}\text { Non-invasive } \\
\text { respiratory support }\end{array}$} \\
\hline $\begin{array}{l}\text { Prolonged inflations } \\
>5 \mathrm{sec}\end{array}$ & $41 / 148(28)$ & $3 / 11(27)$ & $3 / 25(12)$ & 47/184 (26) & 0.248 \\
\hline \multicolumn{6}{|l|}{ Starting CPAP } \\
\hline$\leq 3 \mathrm{cmH}_{2} \mathrm{O}$ & $9 / 149(6)$ & $0 / 0(0)$ & $1 / 21(5)$ & $10 / 180(6)$ & \\
\hline 4-5 $\mathrm{cmH}_{2} \mathrm{O}$ & $114 / 149(77)$ & $6 / 10(60)$ & $19 / 21(90)$ & $139 / 180(77)$ & 0.170 \\
\hline$>5 \mathrm{cmH}_{2} \mathrm{O}$ & 26/149 (17) & $4 / 10(40)$ & $1 / 21(5)$ & $31 / 180(17)$ & \\
\hline \multicolumn{6}{|l|}{$\begin{array}{l}\text { Invasive } \\
\text { respiratory support }\end{array}$} \\
\hline INSURE yes & 43/142 (30) & $4 / 9(44)$ & $4 / 19(21)$ & $51 / 170(30)$ & 0.444 \\
\hline \multicolumn{6}{|l|}{ Surfactant } \\
\hline $100 \mathrm{mg} / \mathrm{kg}$ & $129 / 145(89)$ & $3 / 7(43)$ & $11 / 14(79)$ & $143 / 166(86)$ & 0.002 \\
\hline $150-200 \mathrm{mg} / \mathrm{kg}$ & $16 / 145(11)$ & $4 / 7(57)$ & $3 / 14(21)$ & 23/166 (14) & \\
\hline
\end{tabular}

$\mathrm{FiO}_{2}=$ fraction of inspired oxygen

$\mathrm{CPAP}=$ continuous positive airway pressure

INSURE = intubate, surfactant application, extubate immediately

$\mathrm{SpO}_{2}=$ peripheral saturation of oxygen

$40 \%$ of all units, the highest distribution was seen in AU units (80\%) compared to $41 \%$ (DE) and only $20 \%$ in $\mathrm{CH}$ units $(\mathrm{p}=0.004)$ (Table 2$)$. No information was obtained on whether the units preferred on device over another.

Table three shows the comparison of the targeted values. The only identified significant difference between the countries was regarding the Surfactant treatment: while DE and $\mathrm{CH}$ primarily used $100 \mathrm{ml} / \mathrm{kg}$ as a starting dose, the majority of AU units (57\%) preferred 150-200 ml/ $\mathrm{kg}(\mathrm{p}=0.002)$ (Table 3).

Only minor differences between academic and nonacademic units were found (Table 4 and 5). While head covers were significantly less often used $(p<0.001)$ in academic units, SI-bags were more often used here $(p$ $=0.006$ ), and devices for volume control were used less frequently in academic units $(\mathrm{p}=0.042)$. Regarding the comparison of targeted values, protocols of academic and non-academic of units were widely comparable, except in a weak, however statistically significant difference for the targeted values for $\mathrm{SpO}_{2}(\mathrm{p}$ $=0.023$ ) (Table 5).

Comparison of the DR management of VLBWI from our studied units showed good accordance to the latest ILCOR guidelines 2005, with the exception to the use of $\mathrm{CO}_{2}$-detectors (Table 2). However, we also have observed the widely used incorporation of very recent, high quality evidence as for instance delayed cord clamping [17], gas conditioning or oxygen therapy, irrespective of the lack of a clear statement in the ILCOR 2005 publication [1] (Table 2).

\section{Discussion}

The results from 190 neonatal units from Germany, Austria and Switzerland showed that DR management in these countries was performed at a similar standard and in good accordance with the 2005 ILCOR guide- 
Table 4. Comparison by level of care (academic vs. non-academic clinic) in clinical practice and equipment used for resuscitation of VLBWI (absolute numbers and percent (\%) in parenthesis).

\begin{tabular}{|c|c|c|c|}
\hline & $\begin{array}{l}\text { Academic Hospital } \\
\mathrm{N}=48\end{array}$ & $\begin{array}{l}\text { Non-Academic } \\
\text { Hospital } \\
\mathbf{N}=142\end{array}$ & $\begin{array}{l}\text { Differences } \\
\text { between institutions } \\
\text { p-value }\end{array}$ \\
\hline \multicolumn{4}{|c|}{ Circulatory volume- and temperature control } \\
\hline Late cord clamping & $25 / 48(52)$ & $53 / 131(41)$ & 0.165 \\
\hline Polyethylen foil & $30 / 48(63)$ & $87 / 139(63)$ & 0.991 \\
\hline Head cover & $31 / 48(65)$ & $121 / 139(87)$ & $<0.001$ \\
\hline \multicolumn{4}{|l|}{ Devices for pressure or volume control } \\
\hline FI-bag & $2 / 41(5)$ & $8 / 113(7)$ & 0.624 \\
\hline SI-bag & $44 / 45(98)$ & $102 / 126(81)$ & 0.006 \\
\hline with PEEP valve & $32 / 44(73)$ & $90 / 127(71)$ & 0.814 \\
\hline with manometer & $6 / 43(14)$ & $31 / 116(27)$ & 0.091 \\
\hline Neopuff ${ }^{\circledR}$ & $21 / 44(48)$ & $48 / 127(38)$ & 0.247 \\
\hline Respirator & $15 / 44(34)$ & $57 / 127(45)$ & 0.212 \\
\hline Other pressure control devices & $1 / 47(2)$ & $2 / 136(1)$ & 1.000 \\
\hline Devices without any pressure control & $1 / 40(3)$ & $2 / 112(2)$ & 0.875 \\
\hline Devices with volume control (respirator) & $12 / 48(25)$ & $46 / 135(42)$ & 0.042 \\
\hline \multicolumn{4}{|l|}{$\mathrm{O}_{2}$-therapy and monitoring } \\
\hline Pulse oximetry & $48 / 48(100)$ & 136/138 (99) & 1.000 \\
\hline $\mathrm{O}_{2}$-blenders & $45 / 48(94)$ & $138 / 140(99)$ & 0.106 \\
\hline $\mathrm{CO}_{2}$-detectors & $5 / 48(10)$ & $14 / 138(10)$ & 0.957 \\
\hline Gas heating and humidification & $16 / 48(33)$ & $61 / 137(45)$ & 0.176 \\
\hline
\end{tabular}

FI-bag = flow-inflating bag

Neopuff ${ }^{\circledR}=$ most commonly used T-piece resuscitator

SI-bag $=$ self-inflating bag

PEEP $=$ positive end expiratory pressure

lines. Guidelines for DR management existed in almost all units. Only minor differences were found between countries regarding the provision of a $24 \mathrm{hr}$ neonatal service and presence of a designated resuscitation area, the means for thermal support, the equipment used for giving ventilatory support and regarding the targeted values, or the initial dosage of Surfactant. Apart from the use of head covers and use of devices for volume control (most prevalent in non-academic units) and SI-bags (more prevalent in academic teaching units), as well as different target levels for $\mathrm{SpO}_{2}$ at $10 \mathrm{~min}$. of life, there were no statistically significant differences between academic and non-academic units.

The clinical practice of DR management, as reflected in our survey of protocols of German, Austrian and Swiss neonatal units is discussed below. The protocols were related to the recommendations given by ILCOR in 2005 [1]. With regards to measures for thermal control, significant differences were found between the protocols in German speaking countries and the 2005 ILCOR recommendations: only $63 \%$ of responding units used polyethylen wrappings but $81 \%$ used head covers. Taking into account that these procedures require only inexpensive equipment and little time, and despite good evidence and clear ILCOR recommendations towards their use, it is not clear why these measures were not universally employed [1, 23,
30]. However conversely, although no clear-cut recommendations on late cord clamping were given for preterm neonates in the 2005 ILCOR guidelines, according to our survey $44 \%$ of units already advise to perform late cord clamping $(>30 \mathrm{sec})$, much in line with evidence from a recent meta-analysis [15].

Regarding the use of devices for non-invasive manual ventilatory support, ILCOR 2005 is open towards the use of SI- bags, FI-bags or T-piece resuscitation devices. All devices were considered useful, without specification [1]. However, recent experimental evidence stresses the preference of pressure-controlled devices over SI-bags for giving manual ventilatory support to VLBWIs $[2,18]$. From the results of our survey, we can see that T-piece, pressure controlled ventilation devices are becoming well established for use in the DR (40\%). Use of a pressure manometer together with an SI-bag was current practice in $22 \%$ of units. Regarding ventilation strategies during resuscitation, it is mentioned in the ILCOR guidelines that there was insufficient data to support or refute the routine use of CPAP/PEEP during or immediately after resuscitation in the delivery room [1]. However, although not specified in the 2005 ILCOR guidelines, use of PEEP was commonly employed, the median starting CPAP/PEEP pressure was $5 \mathrm{cmH}_{2} \mathrm{O}$. This value has already been recognized as the median starting CPAP 
Table 5. Comparison by level of care (academic vs. non-academic clinic) in primary target values and parameter settings (absolute numbers and percent (\%) in parenthesis).

\begin{tabular}{|c|c|c|c|}
\hline & $\begin{array}{l}\text { Academic Hospital } \\
\mathrm{N}=48\end{array}$ & $\begin{array}{l}\text { Non-Academic } \\
\text { Hospital } \\
\mathbf{N}=142\end{array}$ & $\begin{array}{l}\text { Differences } \\
\text { between institutions } \\
\text { p-value }\end{array}$ \\
\hline \multicolumn{4}{|l|}{ Oxygen therapy } \\
\hline \multicolumn{4}{|l|}{$\mathrm{FiO}_{2}$} \\
\hline 0.21 & $15 / 45(33)$ & $41 / 138(30)$ & \\
\hline $0.22-0.5$ & $26 / 45(58)$ & $79 / 138(57)$ & 0.728 \\
\hline $0.51-1.0$ & $4 / 45(9)$ & $18 / 138(13)$ & \\
\hline \multicolumn{4}{|l|}{ Target $\mathrm{SpO}_{2}$} \\
\hline$<85 \%$ & $12 / 47(26)$ & $18 / 129(14)$ & \\
\hline $85-90 \%$ & $34 / 47(72)$ & $92 / 129(71)$ & 0.023 \\
\hline$>90 \%$ & $1 / 47(2)$ & $19 / 129(15)$ & \\
\hline High $\mathrm{FiO}_{2}$, taper down & $7 / 48(15)$ & $31 / 140(22)$ & \\
\hline Low $\mathrm{FiO}_{2}$, taper up & $41 / 48(85)$ & $109 / 110(78)$ & 0.260 \\
\hline \multicolumn{4}{|l|}{ Non-invasive respiratory support } \\
\hline Prolonged inflations $>5 \mathrm{sec}$ & $11 / 46(24)$ & $36 / 138(26)$ & 0.770 \\
\hline \multicolumn{4}{|l|}{ Starting CPAP } \\
\hline$\leq 3 \mathrm{cmH}_{2} \mathrm{O}$ & $3 / 45(7)$ & $7 / 135(5)$ & \\
\hline $4-5 \mathrm{cmH}_{2} \mathrm{O}$ & $31 / 45(69)$ & $108 / 135(80)$ & 0.288 \\
\hline$>5 \mathrm{cmH}_{2} \mathrm{O}$ & $11 / 45(24)$ & $20 / 135(15)$ & \\
\hline \multicolumn{4}{|l|}{ Invasive respiratory support } \\
\hline INSURE yes & $12 / 47(26)$ & $39 / 123(32)$ & 0.432 \\
\hline \multicolumn{4}{|l|}{ Surfactant } \\
\hline $100 \mathrm{mg} / \mathrm{kg}$ & $30 / 39(77)$ & $113 / 127(89)$ & 0.109 \\
\hline $150-200 \mathrm{mg} / \mathrm{kg}$ & $9 / 39(13)$ & $14 / 127(11)$ & \\
\hline
\end{tabular}

$\mathrm{CPAP}=$ continuous positive airway pressure

$\mathrm{FiO}_{2}=$ fraction of inspired oxygen

$\mathrm{SpO}_{2}=$ peripheral saturation of oxygen

INSURE = intubate, $\underline{\text { surfactant }}$ application, extubate immediately

level for most German NICUs [19]. Another interesting observation is the discrepancy between the guidelines and common practice as exemplified by the administration of sustained inflations: while mentioned in ILCOR, but not formally suggested in 2005 [1], as many as $26 \%$ of units from the German speaking countries do administer sustained inflations $<5$ sec. during DR management of VLBWI. It can be assumed that those units act on the basis of evidence from two small trials, illustrating some positive effects of sustained inflations [11, 25]. A further deviation from ILCOR 2005 was found regarding the use of $\mathrm{CO}_{2}$ detectors. Such kits can be used for confirming endo-tracheal tube placement and are being recommended for this purpose in the 2005 ILCOR statement [1]. Strikingly, while qualitative and quantitative $\mathrm{CO}_{2}$ detectors were already described to be used by $32 \%$ of North American NICUs in Leone's paper in 2006, two years later, only $10 \%$ of the NICUs from our survey claimed to use these to confirm tracheal tube placement [10]. The reasons for this remain speculative and may warrant further investigation [5]. With respect to gas conditioning, although not specified in the ILCOR guidelines, and as so far only experimental data is available [14], as many as $42 \%$ of units claim to already use heated and humidified gas in the DR. Despite these fine differences to the recommendations by ILCOR 2005, common practice of DR airway management within the German speaking countries is widely in line with the most recently reviewed advances in care of the newly born preterm lung [21, 22].

The particular issue of oxygen administration and peripheral monitoring of oxygenation and the shortcomings of the ILCOR guidelines were already discussed in detail by other colleagues $[8,6]$. In short, while the ILCOR guideline says the supplementation of oxygen should be considered ,if central cyanosis was persistent during resuscitation and hyperoxia should be avoided" [1]. Several recent meta-analyses have helped to educate us on a more judicious use of $\mathrm{O}_{2}$ in the context of delivery room management [24, 16, 20]. The discrepancy between guidelines and most recent evidence on the use of $\mathrm{O}_{2}$ was addressed in a recent publication, aimed for the German readership [6]. According to our survey, only $31 \%$ of the units quoted a starting $\mathrm{FiO}_{2}$ of 0.21 , while $57 \%$ would use a $\mathrm{FiO}_{2}$ of $0.22-0.55$ and just $12 \%$ would use a $\mathrm{FiO}_{2}$ of 
1.0. Also, around $80 \%$ of the surveyed units preferred to start with a low $\mathrm{FiO}_{2}$ and then increase $\mathrm{FiO}_{2}$ if necessary (step up), 20\% would use a step down approach. The ILCOR and ERC guidelines also recommend the use of an incremental approach [1].

A comparison of our results to data on DR management in other European countries yields interesting results. Differences were observed in particular with respect to the airway management and control of oxygen delivery $[8,27]$. When compared to Spanish and Italian data, it becomes obvious that the German speaking countries act consistently on the basis of a written protocol. This was very recently confirmed by the study of Schmölzer et al. [22]. It is not known from the literature whether written protocols were used in other European countries. However, according to Iriondo and co-workers, every neonatal team in Spain employs a neonatologist trained under the national neonatal training scheme, hence a common national DR procedure can be expected [8]. We believe the observed institutional and national differences are very interesting with regards to the question how best evidence is distributed and how it can be most effectively be incorporated in to local guidelines. Data from other European countries should also be obtained in order to survey the local practice guidelines; a copy of our questionnaire is available found in the appendix of this paper.

Further, means to distribute the best available evidence on neonatal resuscitation in order to incorporate it in to common practice should be investigated. Spain, where a common national training programme for neonatologists exists and its completion is compulsory before physicians take over responsibilities in the NICU, may act as a leading example. Other means to keep up to date would be by the use of the internet, with the installation of an evidencebased website with particular focus on neonatal resuscitation. Such a project is currently under construction (www.neonatologie.org).

In conclusion, DR management is based on written protocols and is being operated almost similarly throughout German, Austrian and Swiss neonatal units, and in academic and non-academic units. We found only minor differences regarding the DR setup and equipment used, as well as for targeted values of $\mathrm{SpO}_{2}$ and $\mathrm{FiO}_{2}$. Protocols were in good accordance with the recent 2005 ILCOR guidelines. Where available, emerging high quality evidence that was not in the 2005 ILCOR statement has been adopted into local protocols of many units.

\section{Acknowledgements:}

- Special thanks to the participating representatives of the surveyed clinics in Germany, Austria and Switzerland. A detailed account of the participating institutions can be found in the appendix.

- Parts of the results were presented by Dr. C. C. Roehr as oral presentations at the annual meetings of the GNPI in 2009 and 2010, and at the UK Neonatal Society annual meeting 2009.

- We thank our data management assistants Jessica Blank and Elena Roell for helping with the data acquisition and data management. Thanks to Dr Peter Waugh for the language editing.
Conflicting interest: None of the authors has any conflicting interest.

\section{REFERENCES}

1. American Heart Association, American Academy of Pediatrics. 2005 American Heart Association (AHA) guidelines for cardiopulmonary resuscitation (CPR) and emergency cardiovascular care (ECC) of pediatric and neonatal patients: neonatal resuscitation guidelines. Pediatrics 2006; 117: e978 - e988.

2. Bennett S, Finer NN, Rich W. A comparison of three neonatal resuscitation devices. Resuscitation 2005; 67: 113-8.

3. European Resuscitation Council Guidelines for Resuscitation 2005. Section 6. Paediatric life support. Resuscitation 2005; 67S1: S97 - S133.

4. Fanaroff AA, Stoll BJ, Wright LL, Carlo W, Ehrenkrantz RA, Stark AR, Bauer CR, DonovanEF, Korones SB, Laptook RA, Lemmons JA, Oh W, Papile LA, Shankaran S, Stevensons DK, Tyson JE, Poole WK; NICHD Neonatal Research Network: Trends in neonatal morbidity and mortality for very low birth weight infants. Am J Obstet Gynecol. 2007; 196: 147.e1-147.e8.

5. Garey DM, Ward R, Rich W, Heldt G, Leone T, Finer NN. Tidal volume threshold for colorimetric carbon dioxide detectors available for use in neonates. Pediatrics 2008; 121: e1524-7.

6. Hansmann G, Humpl T, Zimmermann A, Bührer C, Wauer R, Stannigel H, Hoehn T. [ILCOR's new resuscitation guidelines in preterm and term infants: critical discussion and suggestions for implementation]. Klin Padiatr. 2007; 219: 50-7.

7. International Liaison Committee on Resuscitation. 2005 International Consensus on Cardiopulmonary resuscitation and emergency cardiovascular care science with treatment recommendations. Circulation 2005 112: III1-III-136.

8. Iriondo M, Thió M, Burón E, Salguero E, Aguayo J, Vento $\mathrm{M}$; the Neonatal Resuscitation Group (NRG) of the Spanish Neonatal Society (SEN). A survey of neonatal resuscitation in Spain: gaps between guidelines and practice. Acta Paediatr. 2009; 98: 786-91.

9. Jobe AH, Hillman N, Polglase G, Kramer BW, Kallapur $\mathrm{S}$, Pillow J. Injury and inflammation from resuscitation of the preterm infant. Neonatology 2008; 94: 190-6.

10. Leone T, Rich W, Finer N. A Survey of Delivery Room Resuscitation Practices in the United States. Pediatrics 2006; 117; e164-e175.

11. Lindner W, Högel J, Pohlandt F. Sustained pressure-controlled inflation or intermittent mandatory ventilation in preterm infants in the delivery room? A randomized, controlled trial on initial respiratory support via nasopharyngeal tube. Acta Paediatr. 2005; 94: 303-9.

12. Maser T. Teamwork and patient safety in dynamic domains of healthcare: a review of the literature. Acta Anaesthesiol Scand. 2009; 53: 143-51.

13. O'Donnell CJ, Stewart M, Mildenhall M. Neonatal resuscitation in Australia and New Zealand. J Paed Child Heath 2006; 42: 4-5.

14. Pillow JJ, Hillman NH, Polglase GR, Moss TJ, Kallapur SG, Cheah FC, Kramer BW, Jobe AH. Oxygen, temperature and humidity of inspired gases and their influences on airway and lung tissue in near-term lambs. Intensive Care Med. 2009; 35: 2157-63.

15. Rabe H, Reynolds G, Diaz-Rossello J. A systematic review and meta-analysis of a brief delay in clamping the umbilical cord of preterm infants. Neonatology. 2008; 93 : 138-44.

16. Rabi Y, Rabi D, Yee W. Room air resuscitation of the depressed newborn: a systematic review and meta-analysis. Resuscitation 2007; 72: 353-63. 
17. Rajani A, Chitkara R, Halamek L. Delivery Room Management of the Newborn. Pediatr Clin North Am. 2009; 56: 515-35.

18. Roehr CC, Kelm M, Fischer HS, Bührer C, Schmalisch G, Proquitté $\mathrm{H}$. Manual ventilation devices in neonatal resuscitation: tidal volume and positive pressure-provision. Resuscitation 2010; 81: 202-5.

19. Roehr CC, Schmalisch G, Khakban A, Proquitté H, Wauer RR. Use of continuous positive airway pressure (CPAP) in neonatal units - a survey of current preferences and practice in Germany. Eur J Med Res. 2007; 12: 13944.

20. Saugstad OD, Ramji S, Soll RF, Vento M. Resuscitation of newborn infants with $21 \%$ or $100 \%$ oxygen: an updated systematic review and meta-analysis. Neonatology 2008; 94: 176-82.

21. Schmölzer G, Olischar M, Raith W, Resch M, Reiterer F, Müller W, Urlesberger B. Erstversorgung von Neugeborenen. Monatsschr Kinderheilkd 2010; 158: 471-476.

22. Schmölzer GM, Te Pas AB, Davis PG, Morley CJ. Reducing lung injury during neonatal resuscitation of preterm infants. J Pediatr. 2008; 153: 741-5.

23. Soll RF. Heat loss prevention in neonates. J Perinatol. 2008; 28 (Suppl 1): S57-9.

24. Tan A, Schulze A, O'Donnell CP, Davis PG. Air versus oxygen for resuscitation of infants at birth. Cochrane Database Syst Rev. 2005 18; CD002273.

25. tePas AB, Walther FJ. A randomized, controlled trial of delivery-room respiratory management in very preterm infants. Pediatrics 2007; 120: 322-9.

26. Thomas EJ, Sexton JB, Lasky RE, Helmreich RL, Crandell DS, Tyson J. Teamwork and quality during neonatal care in the delivery room. J Perinatol. 2006; 26: 163-9.
27. Trevisanuto D, Doglioni N, Ferrarese P, Bortolus R, Zanardo V; Neonatal Resuscitation Study Group, Italian Society of Neonatology. Neonatal resuscitation of extremely low birthweight infants: a survey of practice in Italy. Arch Dis Child Fetal Neonatal Ed. 2006; 91: F123-4.

28. Vento M, Aguar M, Leone TA, Finer NN, Gimeno A, Rich W, Saenz P, Escrig R, Brugada M. Using intensive care technology in the delivery room: a new concept for the resuscitation of extremely preterm neonates. Pediatrics 2008; 122: 1113-6.

29. Vento M, Cheung PY, Aguar M. The first golden minutes of the extremely-low-gestational-age neonate: a gentle approach. Neonatology 2009; 95: 286-298.

30. Vohra S, Roberts RS, Zhang B, Janes M, Schmidt B. Heat Loss Prevention (HeLP) in the delivery room: a randomized controlled trial of polyethylene occlusive skin wrapping in very preterm infants. J Pediatr. 2004; 145: $750-753$.

Received: September 1, 2010 / Accepted: October 26, 2010

Address for correspondence:

Dr. Charles Christoph Roehr

Department of Neonatology

Charité Universitätsmedizin Berlin

Chariteplatz 1

10117 Berlin

Germany

Tel.: $\quad++49-30-450516052$

Fax: $\quad++49-30-450516920$

Email: christoph.roehr@charite.de

\section{Paticipating Units}

Germany:

- Abt. Allgemeinpädiatrie der Kinderklinik St. Annastift Ludwigshafen

- Abt. für Kinderheilkunde der St.-Antonius-Hospital gGmbH

- Abteilung für Kinder- und Jugendmedizin des Ev. Waldkrankenhaus Berlin Spandau

- Abteilung für Kinderheilkunde des Marienhospital Wesel

- Abteilung für Neonatologie der Asklepios Klinik Barmbek, Hamburg

- Abteilung für Neonatologie des Ludmillenstiftes Meppen

- Abteilung für Neonatologie des Universitätsklinikum Bonn

- Abteilung für Neonatologie, DRK Klinikum Berlin Westend

- Allg. Pädiatrie des Universitätsklinikums Schleswig-Holstein, Kiel

- Dipl.-Med. R. Hanusch, Kinderklinik des Klinikums Obergöltzsch Rodewisch

- Dr. A. Hennenberger, Neonat. päd. Intensivmedizin des Kinderkrankenhauses Wilhelmstift, Hamburg

- Dr. med. A. Zimmermann, Kinderklinik und Poliklinik des Klinikum rechts der Isar, München

Dr. med. Axel von der Wense, Altonaer Kinderkrankenhaus Hamburg

Dr. med. B. Knittel, Kinderklinik 1 des Städt. Klinikums Magdeburg

Dr. med. B. Mackowiak, Neonatologische Intensivmedizin am Ev. Krankenhaus Hamm

- Dr. med. B. Schmidt, Zentrum Josephinchen für Kinder- und Jugendmedizin des St. Joseph-Krankenhauses Berlin

Dr. med. C. Andrée, Zentrum für Kinder- und Jugendmedizin des HELIOS Klinikum Krefeld

- Dr. med. C. Aring, Kinderklinik St. Nikolaus des Allg. Krankenhauses Viersen GmbH

- Dr. med. D. Richter, Abteilung für Kinderheilkunde der Klinik am Eichert, Göppingen

- Dr. med. F. Niemann, Abteilung für Intensivmedizin, Neonatologie der Bergmannshell und Kinderklinik Buer gGmbH Gelsenkirchen

- Dr. med. F. Stemberg, Kinderklinik, Neonatologie des Klinikums Worms

- Dr. med. F. Wild, Kinderklinik St. Elisabeth, Neuburg / Donau

- Dr. med. G. Frey, Südhessisches Perinatalzentrum / Neonatologie Darmstadt

- Dr. med. G. Hammersen, Cnopf'sche Kinderklinik Nürnberg

Dr. med. G. Selzer, Dr. med. P. Lasch, Klinik f. Neonatologie u. päd. Intensivmedizin der Klinikum Bremer-Mitte gGmbH, Bremen

Dr. med. H. Broede, Klinik für Kinder- und Jugendmedizin des Klinikums Detmold

- Dr. med. H. Krull, Klinik für Kinder- und Jugendmedizin der Krankenhaus am Rosarium GmbH (jetzt HELIOS Klinik Sangerhausen), Sangerhausen

- Dr. med. H. Voss, Kinderklinik des Klinikums der Landeshauptstadt Wiesbaden - Dr.-Horst-Schmidt-Kliniken

- Dr. med. H.-G. Hoffmann, Kinder- und Jugendmedizin des Mathias-Spital Rheine

- Dr. med. H.-J. Bittrich, Neonatologie / Kinder IST des HELIOS Klinikums Erfurt 
- Dr. med. H.-U. Peltner, Klinik für Kinderheilkunde und Jugendmedizin des St. Bernward Krankenhauses Hildesheim

- Dr. med. H.T. Körner, Klinik für Kinder- und Jugendmedizin - Intensivstation des Klinikums Links der Weser gGmbH

- Dr. med. I. Hörning-Franz, Neonatologie und päd. Intensivmedizin des Uniklinikums Münster

- Dr. med. I. Müller-Hansen, Abt. Neonatologie der Uniklinik für Kinder- und Jugendmedizin Tübingen

- Dr. med. J. Herrmann, Klinik für Kinder und Jugendliche des Leopoldina-Krankenhauses Schweinfurt

- Dr. med. J. Nawracala, Abt. für Neonatologie des Kinderhospitals Osnabrück

Dr. med. K. Niethammer, Klinik für Kinder und Jugendliche des Klinikums Esslingen

Dr. med. K.-U. Schunck, Klinik für Kinder- und Jugendmedizin, Vivantes Klinikum Berlin Friedrichshain

Dr. med. M. Vochem, Klinik für Kinder- und Jugendmedizin des Olgahospital Stuttgart

- Dr. med. O. Kannt, Klinik für Neonatologie und Neuropädiatrie des HELIOS Klinikums Schwerin

- Dr. med. P. Dahlem, Pädiatrische Intensivmedizin der Klinikum Coburg gGmbH, Coburg

- Dr. med. P. Jesche, Klinik für Kinder- und Jugendmedizin der Klinikum Hoyerswerda gGmbH

- Dr. med. R. Muchow, Kinder- u. Jugendklinik des Klinikums Herford

- Dr. med. R. Vortkamp, Kinderklinik \& Perinatalzentrum der Westpfalz-Klinikum GmbH Kaiserslautern

- Dr. med. S. Thönnißen, Klinik für Kinder- und Jugendmedizin des St. Bonifatius Hospitals Lingen (Ems)

- Dr. med. Saur, Kinderklinik des Ostalb-Klinikums Aalen

Dr. med. St. Seeliger, Klinik für Kinderheilkunde u. Jugendmedizin des Universitätsklinikums Göttingen

Dr. med. T. Hofmann, Abt. für Kinderheilkunde des Klinikums Lippstadt

- Dr. med. T. Hoppen, Klinik für Kinder- und Jugendmedizin des Gemeinschafts-Klinikums Koblenz-Mayen, Koblenz

- Dr. med. U. Spille, Neonatologische und päd. Intensivstation des Klinikums Herford

- Dr. med. V. Arpe, Abt. für Neonatologie der St. Marien-Hospital gGmbH Düren

- Dr. med. V. Boldis, Klinik für Kinder und Jugendliche der ASKLEPIOS Klinikum Uckermark GmbH, Schwedt / Oder

- Dr. med. W. Garbe, Perinatalzentrum / Neonatologie des St.-Marien-Hospitals Bonn

- Dr. med. W. Lehnen, Kinderklinik des St. Clemens Hospitale Sterkrade gGmbH Oberhausen

- Dr. med. W. Müller, Klinik für Kinder- und Jugendmedizin des Krankenhauses Neuwerk, Mönchengladbach

DRK-Kinderklinik Siegen

Josefinum Kinderkrankenhaus Augsburg

Kinder - und Jugendmedizin der GPR Klinikum Rüsselsheim gGmbH

Kinder- und Jugendklinik des Universitätsklinikums Erlangen

- Kinderabteilung der Filderklinik Filderstadt-Bonlenden

- Kinderabteilung des Diakonie-Krankenhauses Bad Kreuznach

Kinderabteilung des Kreiskrankenhauses Traunstein

Kinderabteilung Heidekreisklinikum GmbH Soltau

- Kinderintensivstation des Elbe Klinikums Stade

- Kinderklinik der Allgemeines Krankenhaus gGmbH Hagen

- Kinderklinik der SLK-Kliniken Heilbronn GmbH, Heilbronn

- Kinderklinik der Städt. Kliniken Frankfurt a. M. - Höchst

Kinderklinik des Diak. Werks Kaiserswerth, Krankenanstalten "Florence Nightingale", Düsseldorf

Kinderklinik des Klinikums Aschaffenburg

Kinderklinik des Klinikums Bamberg

- Kinderklinik des Klinikums Hildesheim GmbH

- Kinderklinik des Klinikums Kassel

Kinderklinik des Klinikums Rosenheim

Kinderklinik des Kreiskrankenhauses Waiblingen

- Kinderklinik des Städt. Klinikums Brandenburg a.d. Have

- Kinderklinik des Werner-Forßmann-Krankenhauses Eberswalde

Kinderklinik des Zentralklinikums Suhl

Kinderklinik Dritter Orden, Passau

Kinderklinik u. Poliklinik des Universitätsklinikums Essen

Kinderklinik und Poliklinik des Städtischen Krankenhauses München Schwabing

Kinderkrankenhaus St. Marien des Krankenhaus Landshut

- Klinik für Kinder und Jugendliche der Klinikum Idar-Oberstein GmbH, Idar-Oberstein

- Klinik für Kinder und Jugendliche der Städt. Kliniken Oldenburg gGmbH, Oldenburg

Klinik für Kinder und Jugendmedizin Bad Hersfeld

- Klinik für Kinder- u. Jugendmedizin des Elisabeth-Krankenhauses Reydt Mönchengladbach

- Klinik für Kinder- u. Jugendmedizin des Ev. Krankenhauses Bielefeld

- Klinik für Kinder- u. Jugendmedizin des Klinikums Ludwigsburg

- Klinik für Kinder- u. Jugendmedizin des St.-Agnes-Hospitals Bocholt

Klinik für Kinder- u. Jugendmedizin des Städt. Krankenhauses Kiel

Klinik für Kinder- und Jugendmedizin der Johanniter-Krankenhaus Genthin-Stendal gGmbH

- Klinik für Kinder- und Jugendmedizin der Klinikum Hanau gGmbH, Hanau

- Klinik für Kinder- und Jugendmedizin der Uniklinik des Saarlandes Homburg / Saar

- Klinik für Kinder- und Jugendmedizin des Ernst von Bergmann Klinikums Potsdam

- Klinik für Kinder- und Jugendmedizin des HELIOS Vogtland-Klinikums Plauen

- Klinik für Kinder- und Jugendmedizin des Klinikum Fulda

- Klinik für Kinder- und Jugendmedizin des Krankenhaus Freudenstadt

Klinik für Kinder- und Jugendmedizin des Sana Klinikums Berlin Lichtenberg

- Klinik für Kinder- und Jugendmedizin des St. Georg Klinikums Eisenach gGmbH

- Klinik für Kinder- und Jugendmedizin des St.Elisabeth und St. Barbara- Krankenhauses Halle

Klinik für Kinder- und Jugendmedizin des Städt. Klinikums Karlsruhe gGbmH

- Klinik für Kinder- und Jugendmedizin des Vivantes Klinikums Berlin Neukölln

- Klinik für Neonatologie der Charité, Campus Virchow Klinikum Berlin

- Klinik und Poliklinik für Kinder- und Jugendmedizin des Universitätsklinikums Münster

- Neonatologie / Pädiatrische Intensivmedizin des Städt. Krankenhauses Harlaching, München 
- Neonatologische Intensivmedizin, Klinikum der RWTH Aachen

- Neonatologische und interdisziplinäre pädiatrische Intensivmedizin der Kliniken der Stadt Köln gGmbh

- OA Dipl.-Med. H.U. Thomalla, Kinderklinik \& Ambulanz des Städt. Klinikums Dessau

- OA Dr. med. A. Höck, Klinik für Kinder- und Jugendmedizin des HELIOS Klinikum Berlin Buch

- OA Dr. med. A. Sandvoss, Kinderklinik des Städtischen Klinikums Braunschweig

- OÄ Dr. med. B. Linse, Klinik für Kinder- und Jugendmedizin der Klinikum St. Georg gGmbH

- OA Dr. med. C. Bender, Abt. Neonatologie des Klinikums der Stadt Villingen-Schwenningen GmbH

- OA Dr. med. C. Hünseler, Perinatalzentrum der Uniklinik Köln

- OA Dr. med. C. Willaschek Kinderklinik des Caritaskrankenhauses Bad Mergentheim

- OA Dr. med. D. Kamprad, Klinik für Kinderheilkunde der Klinikum Chemnitz gGmbH

- OA Dr. med. D. Wetzel, Klinik für Kinder- und Jugendmedizin der Thüringen-Klinik

- OÄ Dr. med. Katrin Manzke, Klinik für Kinder- und Jugendmedizin des Dietrich-Bonhoeffer-Klinikums Neubrandenburg

- OA Dr. med. M. Welsch, Abt. für Neonatologie des Klinikums Deggendorf

- OA Dr. med. S. Avenarius, Neonatologie / Päd. Intensivmedizin der Universitätskinderklinik Magdeburg

- OA Dr. med. V. Kunde, neonatologische und pädiatrische Intensivstation der Marienhospital Osnabrück GmbH, Osnabrück

- OA Dr. med. W.E. Boehm et al., Neonatologie und päd. Intensivmedizin der DRK-Kinderklinik Siegen gGmbH, Siegen

- OA Dr. R. Haase und OÄ Dr. med. U. Lieser, Neonatologie u. päd. Intensivmedizin des Universitätsklinikums Halle (Saale)

- Päd. Intensivmedizin u. Neonatologie, Perinatalzentrum des HELIOS Klinikums Wuppertal

- Pädiatrische Abteilung des St. Elisabeth Krankenhauses Neuwied

PD Dr. med. A. Hübler, Neonatologie und Pädiatrische Intensivmedizin des Universitätsklinikums Jena

PD Dr. med. B. Bohnhorst, Päd. Pneumologie und Neonatologie der Medizinischen Hochschule Hannover

PD Dr. med. B. Erdlenbruch, Klinik für Kinder und Jugendmedizin des Johannes Wesling Klinikums Minden

PD Dr. med. C. Roll, Kinder- u. Jugendklinik der Universität Witten / Herdecke, Datteln

PD Dr. med. J. Dembinski, Klinik für Kinder- und Jugendmedizin der Ruppiner Kliniken GmbH Neuruppin

- PD Dr. med. R. Hentschel, Zentrum f. Kinderheilkunde und Jugendmedizin des Klinikums Freiburg

PD Dr. med. Th. Erler, Klinik für Kinder- und Jugendmedizin des Carl-Thiem-Klinikums Cottbus

Perinatalzentrum Neonatologie an der Frauenklinik der Ludwig-Maximilian-Universität, München

Prof. Dr. G. Buheitel, Klinik für Kinder und Jugendliche des Klinikums Augsburg

- Prof. Dr. med. Dipl. Chem. J. Pöschl, Abteilung Neonatologie der Universitätsklinik für Kinder- und Jugendmedizin, Heidelberg

- Prof. Dr. med. E. Kattner, Kinderkrankenhaus auf der Bult, Hannover

- Prof. Dr. med. H. Hummler, Universitätsklinik für Kinder- und Jugendmedizin Ulm

- Prof. Dr. med. H. Segerer, Abt. für Neonatologie der Klinik St. Hedwig, Krankenhaus Barmherzige Brüder Regensburg

- Prof. Dr. med. M. Rüdiger, Abt. für Neonatologie u. Intensivmedizin des Universitätsklinikums "Carl Gustav Carus", Dresden

- Prof. Dr. med. P. Haas, Klinik für Kinder- und Jugendmedizin der Ernst-Moritz-Arndt Universität Greifswald

- Prof. Dr. med. R. Galaske, Klinik für Kinder und Jugendliche der SHG Kliniken Merzig

- Prof. Dr. med. U. Thome, Universitätsklinik und Poliklinik für Kinder- und Jugendliche Leipzig

Prof. Dr. W. Nikischin, Neugeborenen-Intensivstation des Universitätsklinikum Schleswig-Holstein

Sektion Neonatologie und Pädiatrische Intensivmedizin des Universitätsklinikums Hamburg-Eppendorf

- Universitäts-Kinderklinik Würzburg

- Zentrum der Kinderheilkunde des Universitätsklinikums Frankfurt / Main

\section{Swizerland}

- Dr. P. Diebold, Médecin-Chef, Hopital du Chablais, Aigle

- Dr. M. Wopmann, Kantonsspital Baden

- Prof. Dr. Chr. Bührer, Universitäts-Kinderspital beider Basel, Neonatologie, Basel

- Dr. R. Glanzmann, UKBB Basel/Bruderholz

PD Dr. M. Nelle, Neonatologie, Med. Univ.-Kinderklinik, Inselspital, Bern

Dr. Ph. Curchod, Hospitaliers du Nord Vaudois, Yverdon-les-Bains, Champlon

Dr. Brigitte Scharner, Kantonsspital Graubünden, Dep. F. Kinder- u. Jugendmedizin, Chur

- Dr. Anita Truttmann, Médecin associè PD MER CHUV, Division de Néonatologie, Lausanne

- Dr. D. Dell' Allolino, Oberarzt Pädiatrie, Luzern

- PD Dr. Th. Berger, Kinderspital Luzern, NeolPS, Luzern

- Dr. Zemmouri, Hopital de Morges, pediatrie Morges

- PD Dr. B. Laubscher, Hopital Pourtalès, Pèdiatre FMH, Neuchatel

- Dr. E. Pythoud, Médecin-chef du Service Hopital intercantonal de la Broye, Payerne

- Prof. Dr. Bianchetti, OBV Mendrisio Pediatria + Ginec, Mendrisio Kinderspital St. Gallen

- Dr. M.-A. Panchard, L'Hopital Riviera, Service du pédiatrie, Vevey

Dr. Roten, Praxis Spitalzentrum Oberwallis, Viége

- Dr. U. Zimmermann, Kinder- u. Jugendmedizin, Neonatologie, Winterthur

PD Dr. J.-C. Fauchère, Klinik für Neonatologie, Univ.-Spital Zürich

\section{Austria}

- Prim. Dr. B. Ausserer, Krankenhaus Dornbirn, Kinder- und Jugendheilkunde, Dornbirn

- Univ.Prof. Dr. G. Simbruner, Univ.-Klinik für Kinder- u. Jugendmedizin, Innsbruck

- Prim. Dr. Claudia Haberland, Bezirkskrankenhaus Kufstein, Kinder- u. Jugendheilkunde, Kufstein

- Dr. M. Weissensteiner, Landes-Frauen- und Kinderklinik Linz, Linz

- Prim. Dr. W. Müller, A.ö. Bezirkskrankenhaus, Kinder- u. Jugendstation, Reutte

- Prim. Dr. J. Rücker, Salzburger Landeskliniken, Neonatologie, ITS, Salzburg

- Univ.-Kinder- und Jugendheilkunde, Neonatologie, Magistrat der Stadt Wien, Allgem. Krankenhaus, Wien

- Prim. Dr. K. Gutenberger, Krankenhaus St. Vinzenz, Kinder- u. Jugendheilkunde, Zams 


\section{Questionnaire}

Fragebogen zu Ausstattung und Vorgehen in der Frühgebornenreanimation in Österreich, BRD und Schweiz

Die u. g. Antworten stammen von einer Einrichtung / Krankenhaus aus

口 Deutschland

口 Österreich

口 Schweiz

Angaben zur Einrichtung:

$\boldsymbol{u}$ universitäre Kinderklinik $\boldsymbol{\square}$ nicht-universitäre Kinderklinik

Anzahl der Neugeborenen im Verantwortungsbereich (angeschlossene Geburtskliniken) pro Jahr

$\boldsymbol{\square}<1000 \quad \square>1000$

Anzahl der Erstversorgungen von Kindern mit Geburtsgewicht unter $1500 \mathrm{~g}$

口 $<50 \quad \square>50$

Neonatologischer Versorgungsdienst im Haus 24 Std. verfügbar

$\square$ nein $\square$ ja

Haben Sie festgeschriebene Richtlinien bzgl. des Umgangs mit Frühgeborenen

$\boldsymbol{\square}$ nein $\boldsymbol{\square}$ ja (wenn ja, dann würden wir uns über ein Exemplar dieser Richtlinie freuen, bitte beilegen)

Die folgenden Fragen beziehen sich auf die Erstversorgung eines Frühgeborenen < $1500 \mathrm{~g}(\mathrm{VLBW}-\mathrm{FG})$ Wie verfahren Sie in Ihrem Hause?

Perinatales Management:

Praktizieren sie das Tiefhalten des Kindes unter Plazenta-Niveau (mind. 30 sek.)

Benutzen Sie Plastikfolien zum Abdecken des Kindes

Benutzen Sie Kopfbedeckungen (Mützen)

Reanimation:

Ort der Frühgeborenenreanimation
口 Kreissaal
口 Erstversorgungsraum
$\square$ neonatologische Station

Nutzen Sie bei der Frühgeborenenreanimation

- flussabhängige Atemhilfen (Anaesthesie-Beutel)

- selbst entfaltende Beatmungsbeutel (z.B. Laerdal ${ }^{\circledR}$ - oder Ambu ${ }^{\circledR}$-Beutel)

- Beatmungsbeutel mit PEEP-Kontrolle

- Beatmungsbeutel mit Druckmanometer

- druckkontrollierte Atemhilfe

wenn ja,

$\square$ Perivent ${ }^{\circledR} \quad \square$ Respirator $\square$ andere druckkontrollierte Atemhilfe:

- Pulsoximetrie (periphere $\mathrm{SpO}_{2}$-Messung)

- Nutzen $\mathrm{Sie} \mathrm{CO}_{2}$-Detektoren zur Evaluation erfolgreicher Intubation

$\square$ kolometrische $\mathrm{CO}_{2}$-Detektoren $\quad$ Infrarot-Sensoren (z.B. Cosmo-Plus ${ }^{\circledR}$ )

- eine Sauerstoff-Mischeinheit für stufenlose $\mathrm{FiO}_{2}$-Einstellung

- eine Volumenkontrolle unter Beatmung

- Atemgasbefeuchtung ab der 1. Atemgasgabe

Sauerstoff
Primäre Atemgaswahl $\left(\mathrm{FiO}_{2}\right)$ :
ㅁ 0,21
ㅁ $0,22-0,5$
ㅁ $0,51-1,0$

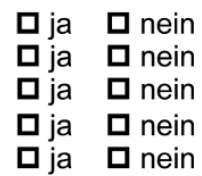

Wo liegt für Sie der Zielwert der peripheren $\mathrm{O}_{2}$-Sättigung eines VLBW-FG ab der 10. Lebensminute (LM)? ㅁ $80-85 \%$ ㄴ $<85 \%$ $85-90 \%$ ㅁ $90-95 \%$ ㅁ $>95 \%$

$\mathrm{Ab}$ welchem $\mathrm{SaO}_{2}\left(>10\right.$. LM) reichern Sie das Atemgas mit $\mathrm{O}_{2}$ an?
ㄷ $<80 \%$
口 $80-85 \% \quad$ 口 $86-90 \%$
ㅁ $91-95 \%$
ㅁ $>96 \%$

Bei der Dosierung des $\mathrm{FiO}_{2}$, bevorzugen Sie zuerst eine

$\square$ niedrige $\mathrm{O}_{2}$-Konzentration oder $\square$ hohe $\mathrm{O}_{2}$-Konzentration, und dann die entspr. Bedarfsangleichung?

Nicht invasive Atemunterstützung

- praktizieren Sie ein sog. Blähmanöver (PIP > $15 \mathrm{~cm} \mathrm{H}_{2} \mathrm{O}$. Ziel: Rekrutierung von FRC) $\boldsymbol{\square}$ ja $\boldsymbol{\square}$ nein

wenn Blähmanöver, dann über $\mathbf{G}$ Gesichtsmaske

$\square$ nasaler Tubus

$\square<5$ Sek. Blähmanöver $\quad \square>5$ Sek. Blähmanöver

- wie hoch ist Ihr angewandter CPAP-Anfangsdruck, bzw. PEEP

$\square \leq 3 \mathrm{~cm} \mathrm{H} \mathrm{H}_{2} \mathrm{O} \quad 4-5 \mathrm{~cm} \mathrm{H} \mathrm{H}_{2} \mathrm{O} \quad 6-7 \mathrm{~cm} \mathrm{H}_{2} \mathrm{O} \quad \square \geq 8 \mathrm{~cm} \mathrm{H}_{2} \mathrm{O}$

- flow unter CPAP
$\square<31 / \mathrm{min}$
ㄱ $3-41 / \mathrm{min}$
ㅁ 5 - $6 \mathrm{l} / \mathrm{min}$
口 $>6 \mathrm{l} / \mathrm{min}$

Intubation und Surfactantgabe

- prophylaktische Surfactantgabe

wenn ja, ab welchem Gestationsalter

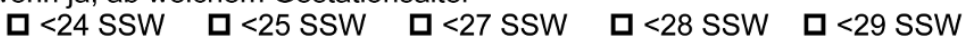

- nur bei klinisch manifestem Atemnotsyndrom?

- Surfactantgabe i.S. von INSURE (primäre INtubation - SURfactant - sofortige Extubation)

- Surfactantgabe unter Spontanatmung via Sonde

- Surfactant-Menge $\quad$ व $100 \mathrm{mg} / \mathrm{Kg}$ ㅁ $150 \mathrm{mg} / \mathrm{Kg}$ 口 $200 \mathrm{mg} / \mathrm{Kg}$

$\square$ ja $\square$ nein

$\square$ ja $\square$ nein

$\square$ ja $\square$ nein

$\square$ ja nein

$\square$ ja $\square$ nein

Sollen wir Ihre Einrichtung im Anhang der Auswertung / Publikation namentlich erwähnen?

$\mathbf{\square}$ ja nein

Wenn ja, dann geben Sie bitte hier Ihre Adresse an, bzw. tragen hier Ihren Stempel auf:

Vielen Dank! 